\title{
Eriocortex eriocauli, gen. et sp. nov. (Ustilaginomycetes) from Australia
}

\section{Kálmán Vánky ${ }^{1 *}$, Roger G. Shivas ${ }^{2}$, Matthew D. Barrett ${ }^{3} \&$ Matthias Lutz ${ }^{4}$}

\author{
${ }^{1}$ Herbarium Ustilaginales Vánky (H.U.V.), Gabriel-Biel-Str. 5, D-72076 Tübingen, Germany \\ ${ }^{2}$ Plant Pathology Herbarium, Biosecurity Queensland, Ecosciences Precinct, Dutton Park, Qld 4102, \\ Australia \\ ${ }^{3}$ Botanic Gardens and Parks Authority, Fraser Ave, West Perth, WA 6005; School of Plant Biology, Faculty \\ of Natural and Agricultural Sciences, The University of Western Australia, Crawley, 6009, Western Australia \\ and c/- Western Australian Herbarium, Department of Environment and Conservation, Locked Bag 104, \\ Bentley Delivery Centre, 6983, Western Australia \\ ${ }^{4}$ Evolutionäre Ökologie der Pflanzen, Institut für Evolution und Ökologie, University of Tübingen, Auf \\ der Morgenstelle 1, D-72076 Tübingen, Germany
}

Received 5 December 2012 / Accepted 18 December 2012 / Published 11 January 2013

Vánky, K., Shivas, R.G., Barrett, M.D. \& Lutz, M. 2013. Eriocortex eriocauli, gen. et sp. nov. (Ustilaginomycetes) from Australia. - Mycobiota 1: 9-16. doi: 10.12664/mycobiota.2013.01.02

Abstract. A new genus, Eriocortex is proposed to accommodate a peculiar, new smut fungus, E. eriocauli, collected in Australia on Eriocaulon scullionii.

Key words: Basidiomycota, Eriocaulaceae, Eriocortex, Eriocortex eriocauli, molecular phylogenetics, plant pathogens, smut fungi, taxonomy

\section{Introduction}

Eriocaulon L. is a genus of about 400 species, mainly in the tropics. It belongs to the Eriocaulaceae of the order Poales (for relationship see Bremer et al. 2003: 30-31). On Eriocaulon six smut fungi are known in four genera (Vánky 2011): Eriocaulago eriocauli (Massee) Vánky, E. jagdishwari (Mishra) Vánky, Eriomoeszia eriocauli (G.P. Clinton) Vánky, Eriosporium hessii (E. Müll.) Vánky, E. mesanthemi (E. Müll.) Vánky, and Tolyposporella eriocaulonis Vienn.-Bourg.

\footnotetext{
*Corresponding author: e-mail: vanky.k@cityinfonetz.de
} 
Recently a smut fungus was collected on Eriocaulon scullionii in Australia, different from all known smut fungi on Eriocaulaceae, both on species and generic level. It is described below. This is the first smut fungus on Eriocaulaceae from Australia (Vánky \& Shivas 2008).

\section{Materials and methods}

The specimen examined in this study is listed below. The voucher specimen has been deposited in BRIP and H.U.V. The latter abbreviation refers to the personal collection of Kálmán Vánky, "Herbarium Ustilaginales Vánky" currently held at his home (GabrielBiel-Straße 5, D-72076 Tübingen, Germany). Nomenclatural novelties were registered in MycoBank (www.MycoBank.org, Crous et al. 2004). The genetype concept follows the proposal of Chakrabarty (2010).

\section{Morphological examination}

Spore ball and spore characteristics were studied using dried herbarium specimens. For light microscopy (LM) spore balls were suspended in a small droplet of lactophenol, covered with a cover glass, gently heated to boiling point to rehydrate the spore balls and eliminate air bubbles from the preparation. For study of the spores inside the balls, some of the spore balls were crushed by applying pressure on the cover glass with a soft piece of wood (matchstick), under a stereo microscope, and examined by LM at 1000× magnification. For scanning electron microscopy (SEM), spore balls (partly squashed with a lancet) were placed on double-sided adhesive tape, mounted on a specimen stub, sputter-coated with gold-palladium, ca $20 \mathrm{~nm}$, and examined in a SEM at $10 \mathrm{kV}$.

\section{DNA extraction, PCR, and sequencing}

For methods of isolation and crushing of fungal material, DNA extraction, amplification of the 5'-end of the nuclear large subunit ribosomal DNA (LSU, about $650 \mathrm{bp}$ ), purification of PCR products, sequencing, and processing of the raw data see Lutz et al. (2012). The DNA sequence determined for this study was deposited in GenBank (GenBank accession number: KC184905).

\section{Phylogenetic analyses}

The Eriocortex eriocauli specimen examined in this study is listed below. To elucidate the phylogenetic position of the specimen its LSU sequence was analysed within a dataset covering all ustilaginaceous genera of which sequences were available in GenBank except for Restiosporium and Websdanea. Sequences were from Begerow et al. (1997), Piepenbring et al. (1999), Hendrichs et al. (2005), Stoll et al. (2005), Matheny et al. (2006), Vánky et al. (2006), Bauer et al. (2007), Begerow et al. (2007), González et al. (2007), Vánky \& Lutz (2011), Lutz et al. (2012). GenBank accession numbers are given in Fig. 7. If present in GenBank the respective type species were used.

Sequence alignment was obtained according to Lutz et al. (2012) with the following GBlocks options. 'Minimum Number of Sequences for a Conserved Position': 14, 'Minimum Number of Sequences for a Flank Position': 14, 'Maximum Number of Contiguous Non- 
conserved Positions': 8, 'Minimum Length of a Block': 5, and 'Allowed Gap Positions' to 'With half'.

The resulting alignment (new number of positions: 604. 29\% of the original 2037 positions; number of variable sites: 222) was used for phylogenetic analyses using a Bayesian Approach and Maximum Likelihood (ML) according to Lutz et al. (2012).

In line with the results of Begerow et al. 2007 and Lutz et al. 2012, trees were rooted with Pericladium grewiae.

\section{Results and discussion}

The different runs of the Bayesian phylogenetic analyses that were performed and the ML analyses yielded consistent topologies. To illustrate the results, the consensus tree of one run of the Bayesian phylogenetic analyses is presented (Fig. 7). Estimates for a posteriori probabilities are indicated on branches before slashes, numbers on branches after slashes are ML bootstrap support values.

In all analyses the Eriocortex eriocauli specimen clustered together with Eriomoeszia eriocauli, Leucocintractia scleriae, Macalpinomyces eriachnes, Moesziomyces bullatus, Tranzscheliella hypodytes, Ustanciosporium standleyanum, and the cluster of six genera related to Ustilago. However, support for any relationships between the latter group and the former species was low apart from the close relation of Ustanciosporium standleyanum and Leucocintractia scleriae. None of the analyses revealed support for a common lineage of Eriocortex eriocauli and any other genus. Thus molecular phylogenetic analyses using the LSU neither support nor contradict the erection of a distinct genus for the smut on Eriocaulon scullionii.

Eriocortex Vánky \& R.G. Shivas, gen. nov.

MYcoBAnK MB 802773

Sori in ovariis plantarum nutrientium familiae Eriocaulaceae, capsulas massa atre colorata glomerulorum sporarum implentes. Peridium fungale, columella et cellulae steriles nullae. Glomeruli sporarum e sporis et cortice duro compositi. Sporae pigmentatae (flavobrunnaeae, non violaceo-vel rubrotinctae). Typus generis Eriocortex eriocauli.

Sori in ovaries of host plants in Eriocaulaceae, filling the capsules with dark coloured masses of spore balls. Fungal peridium, columella and sterile cells lacking. Spore balls composed of spores and a hard cortex. Spores pigmented (yellowish brown, without violet or red tint).

Typus generis: Eriocortex eriocauli.

Etymology: Erio- from Eriocaulaceae, -cortex Latin = cortex, outer layer, referring to the hard, cortical layer of the spore balls.

Eriocortex eriocauli R.G. Shivas, Vánky, M.D. Barrett \& M. Lutz, sp. nov. $\quad$ Figs 1-6. MycoBAnK MB 802774

Typus in matrice Eriocaulon scullionii G.J. Leach, Australia, Western Australia, Kimberley Region, $3 \mathrm{~km}$ NNE of Prince Regent River from E boundary of Prince Regent 
Nature Reserve (1 km E of reserve), 1550'34.5” S, 125\%41'40.6” E, alt. c. $570 \mathrm{~m}$, 22.IV.2008, leg. R.L. Barrett 4560B (holotypus, BRIP 54 346; isotypus H.U.V. 21 964).

Sori in nonnullis capsulis inflorescentiae, eas massa nigra, granuloso-pulverea glomerulorum sporarum implentes, ovariorum vicem tenuens. Glomeruli sporarum globosi, ovoidei, late ellipsoidales, subpolyedrice raro trianguliter irregulares, 40-120 × 45-145 $4 \mathrm{~m}$, atro-rubrobrunnei, subopaci, permanentes, pressu duro frangentes, ex sporis pluribus decem usque nonnullis centum acie contiguis, facile separabilibus et cortice fungali tenuo, atro, duro compositi. Sporae globosae, ellipsoidales usque subpolyedrice irregulariter rotundatae, 8-12 $\times$

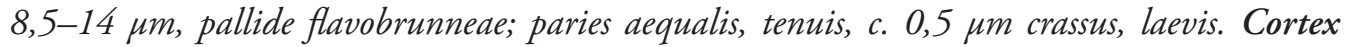
2-4 $\mu \mathrm{m}$ crassus, atro-rufobrunneus, compositus e cellulis fungalibus sterilibus arcte contiguis intertextis et conglutinatis, brevibus vel elongatis, irrgularibus, 1,5-2,5 $\mathrm{mm}$ crassis, 8-20 $\mathrm{mm}$ longis; pariete parum inaequali, 0,5-1 $\mu m$ crasso. Cellulae steriles absentes.

Sori (Figs 1,2) in some capsules of an inflorescence, filling them with a black, granularpowdery mass of spore balls, replacing the ovaries, liberated by the opening of the capsules but hidden by the floral envelopes. Spore balls (Figs 3, 6) globose, ovoid, broadly ellipsoidal, subpolyhedrally, rarely triangularly irregular, 40-120 × 45-145 $\mu \mathrm{m}$, dark reddish brown, subopaque, permanent, breaking by hard pressure, composed of several tens to some hundreds of tightly packed, easily separating spores, and a thin, dark, hard, fungal cortex. Spores (Fig. 4) globose, ellipsoidal to rounded subpolyhedrally irregular, 8-12 × 8.5-14 $\mu \mathrm{m}$, pale yellowish brown; wall even, thin, c. $0.5 \mu \mathrm{m}$ thick, smooth. Cortex (Figs 3-5) 2-4 $\mu \mathrm{m}$ thick, dark reddish brown, composed of tightly packed, interwoven and conglutinated structure of short or elongated, irregular, often bent or even ramifying sterile fungal cells, 1.5-2.5 $\mu \mathrm{m}$ wide, 8-20 $\mu \mathrm{m}$ long; wall slightly uneven, $0.5-1 \mu \mathrm{m}$ thick. Sterile cells absent.

The LSU genetype sequence is deposited in GenBank with the accession number KC184905.

Key to the genera of smut fungi on Eriocaulaceae

1 Sori in the leaves and stems forming lead coloured, compact striae . . . Tolyposporella

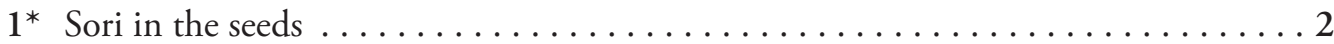

2 Spores single ....................... Eriocaulago

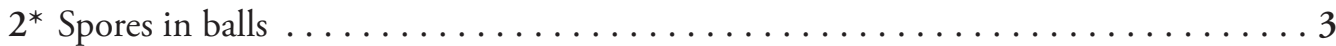

3 Spore balls covered by a cortex $\ldots \ldots \ldots \ldots \ldots \ldots \ldots \ldots \ldots \ldots \ldots \ldots \ldots \ldots$

3* Spore balls not covered by a cortex . . . . . . . . . . . E Eriosporium

4 Spores in the balls mixed with and connected by sterile cells . . . . . . . Eriomoeszia

$4^{*}$ Spores in the balls not mixed with sterile cells . . . . . . . . . . . Eriocortex 

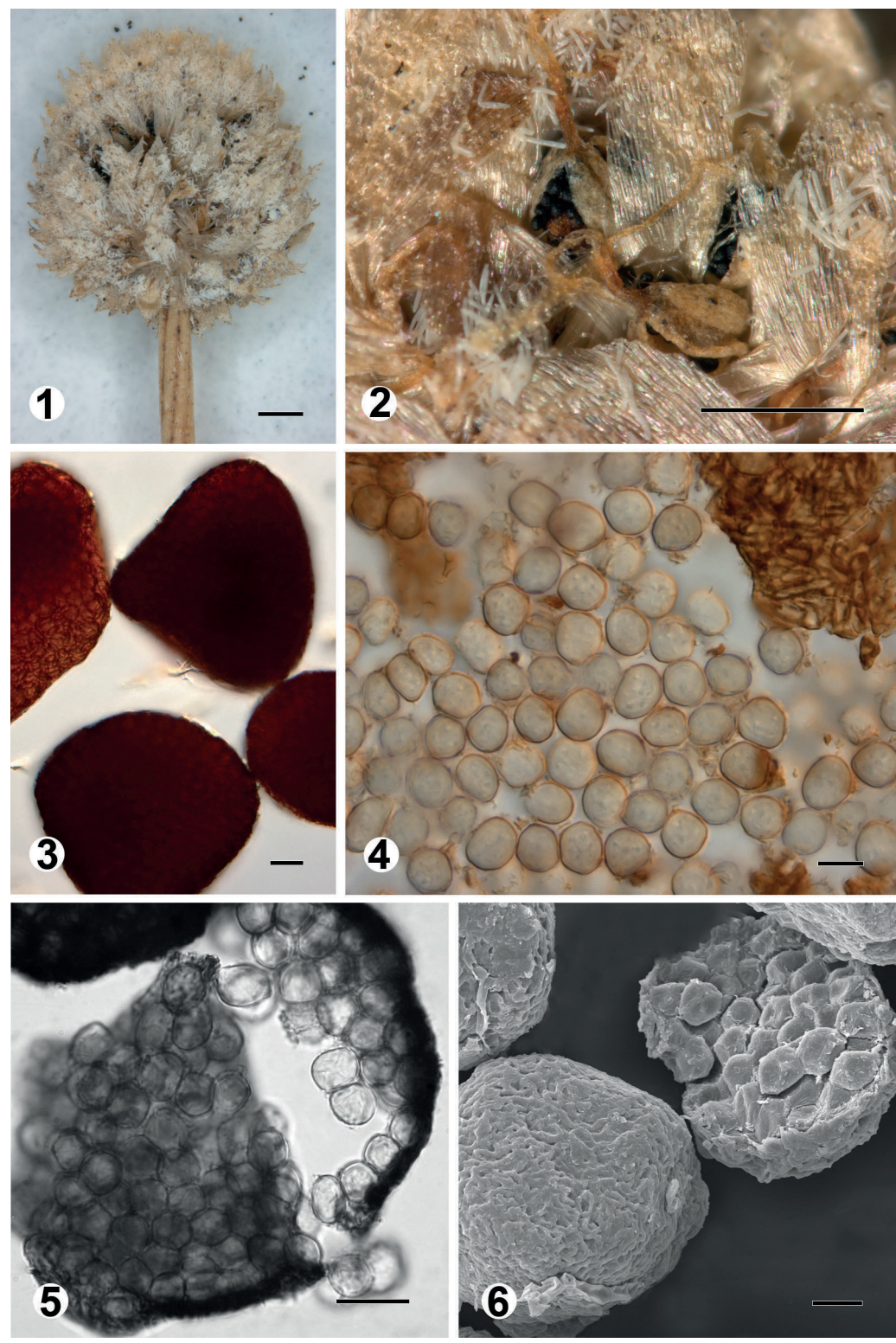

Fig. 1. Sori of Eriocortex eriocauli (type) in some capsules of an inflorescence of Eriocaulon scullionii. Bar $=1 \mathrm{~mm}$. Fig. 2. Infected flowers with capsules filled by spore balls of Eriocortex eriocauli (type). Bars $=1 \mathrm{~mm}$. Fig. 3. Spore balls of Eriocortex eriocauli (type) in LM. Bar $=20 \mu \mathrm{m}$. Fig. 4. Spores of Eriocortex eriocauli (type) in LM. Bar $=10 \mu \mathrm{m}$. Fig. 5. Squashed spore ball showing the cortex and spores of Eriocortex eriocauli (type) in LM. Note the dark cortical layer on the free surface of the outermost spores of the spore ball. Bar $=10 \mu \mathrm{m}$. Fig. 6. Two spore balls, of which one is broken open, showing the cortex and spores of Eriocortex eriocauli (type) in SEM. Bar $=10 \mu \mathrm{m}$ 


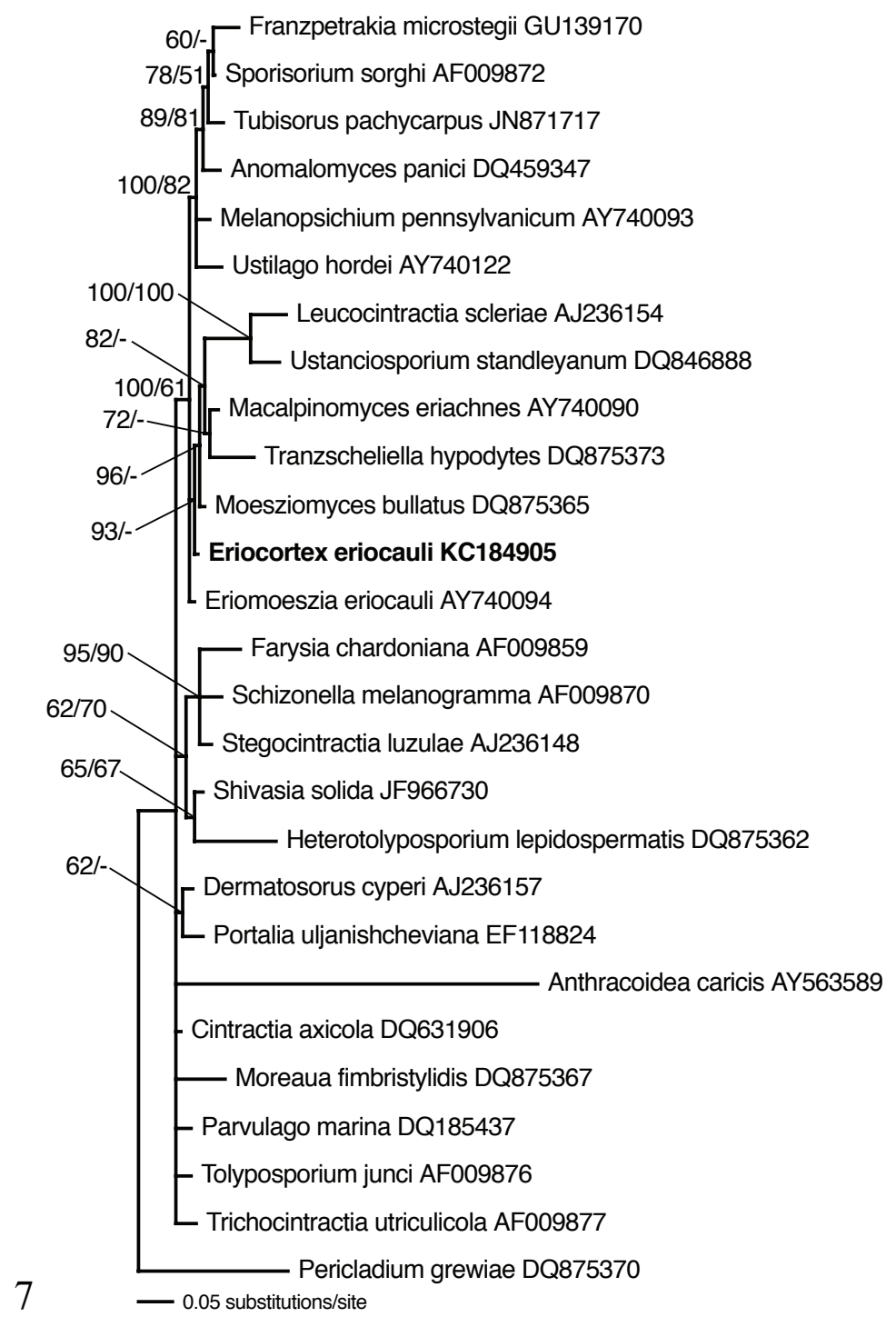

Fig. 7. Bayesian inference of phylogenetic relationships within the sampled Ustilaginaceae: Markov chain Monte Carlo analysis of an alignment of LSU sequences using the GTR+I+G model of DNA substitution with gamma distributed substitution rates and an estimated proportion of invariant sites, random starting trees and default starting parameters of the DNA substitution model. A 50\% majority-rule consensus tree is shown computed from 45000 trees that were sampled after the process had reached stationarity. The topology was rooted with Pericladium grewiae. Numbers on branches before slashes are estimates for a posteriori probabilities, numbers on branches after slashes are ML bootstrap support values. Branch lengths were averaged over the sampled trees. They are scaled in terms of expected numbers of nucleotide substitutions per site. 
There is an additional, monospecific genus, Centrolepidosporium R.G. Shivas \& Vánky (2007: 2) that has spore balls composed of spores and a cortex of sterile cells. Its type, C. sclerodermum R.G. Shivas \& Vánky produces systemic infection of Centrolepis exerta (R. Br.) Roem. \& Schult. (Centrolepidaceae) destroying the seeds. Eriocortex differs from Centrolepidosporium in that (i) the host belongs to another plant family, (ii) infection is localised, and (iii) the cortex is composed of interwoven ramifying cells.

Acknowledgements. The authors are grateful to Dr Sándor Tóth (Gödöllö, Hungary) for providing the Latin descriptions. The technical assistance of Mrs. Christine Vánky (H.U.V., Tübingen, Germany) with the illustrations, and Mrs. Monika Meinert (University of Tübingen) with preparation of the SEM picture of the spores, is gratefully acknowledged. We thank Michael Weiß, Sigisfredo Garnica, and Robert Bauer (Tübingen) for providing facilities for molecular analyses.

\section{References}

Bauer, R., Lutz, M., Piątek, M., Vánky, K. \& Oberwinkler, F. 2007. Flamingomyces and Parvulago, new genera of marine smut fungi (Ustilaginomycotina). - Mycological Research 111: 1199-1206. doi: 10.1016/j.mycres.2007.06.018

Begerow, D., Bauer, R. \& Oberwinkler, F. 1997. Phylogenetic studies on nuclear LSU rDNA sequences of smut fungi and related taxa. - Canadian Journal of Botany 75: 2045-2056. doi: 10.1139/b97-916

Begerow, D., Stoll, M. \& Bauer, R. 2007('2006'). A phylogenetic hypothesis of Ustilaginomycotina based on multiple gene analyses and morphological data. - Mycologia 98: 906-916. doi: 10.3852/ mycologia.98.6.906

Bremer, K., Bremer, B. \& Thulin, M. 2003. Introduction to phylogeny and systematics of flowering plants. - Symbolae Botanicae Upsalienses 33(2): 1-102.

Chakrabarty, P. 2010. Genetypes: a concept to help integrate molecular phylogenetics and taxonomy. Zootaxa 2632: 67-68.

Crous, P.W., Gams, W., Stalpers, J.A., Robert, V. \& Stegehuis, G. 2004. MycoBank: an online initiative to launch mycology into the $21^{\text {st }}$ century. - Studies in Mycology 50: 19-22.

González, V., Vánky, K., Platas, G. \& Lutz, M. 2007. Portalia gen. nov. (Ustilaginomycotina). - Fungal Diversity 27: 45-59.

Hendrichs, M., Begerow, D., Bauer, R. \& Oberwinkler, F. 2005. The genus Anthracoidea (Basidiomycota, Ustilaginales): a molecular phylogenetic approach using LSU rDNA sequences. - Mycological Research 109: 31-40. doi: 10.1017/S0953756204001686

Lutz, M., Vánky, K. \& Piatek, M. 2012. Shivasia gen. nov. for the Australasian smut Ustilago solida that historically shifted through five different genera. - IMA Fungus 3: 143-154. doi: 10.5598/ imafungus.2012.03.02.06

Matheny, P.B., Gossmann, J.A., Zalar, P., Arun Kumar, T.K. \& Hibbett, D.S. 2006. Resolving the phylogenetic position of the Wallemiomycetes: an enigmatic major lineage of Basidiomycota. - Canadian Journal of Botany 84: 1794-1805. doi: 10.1139/b06-128 
Piepenbring, M., Begerow, D. \& Oberwinkler, F. 1999. Molecular sequence data assess the value of morphological characteristics for a phylogenetic classification of species of Cintractia. - Mycologia 91: 485-498. doi: 10.2307/3761349

Shivas, R.G. \& Vánky, K. 2007. Centrolepidosporium sclerodermum gen. et sp. nov. (Ustilaginomycetes) from Australia. - Mycologia Balcanica 4: 1-4.

Stoll, M., Begerow, D. \& Oberwinkler, F. 2005. Molecular phylogeny of Ustilago, Sporisorium, and related taxa based on combined analyses of rDNA sequences. - Mycological Research 109: 342-356. doi: $10.1017 /$ S0953756204002229

Vánky, K. 2011('2012'). Smut fungi of the world. APS Press, St. Paul, USA.

Vánky, K. \& Lutz, M. 2011. Tubisorus, a new genus of smut fungi (Ustilaginomycetes) for Sorosporium pachycarpum. - Mycologia Balcanica 8: 129-135.

Vánky, K. \& Shivas, R.G. 2008. Fungi of Australia: The Smut Fungi. ABRS, Canberra: CSIRO Publishing, Melbourne.

Vánky, K., Lutz, M. \& Shivas, R.G. 2006. Anomalomyces panici, new genus and species of Ustilaginomycetes from Australia. - Mycologia Balcanica 3: 119-126. 